\title{
Tumour necrosis factor and Crohn's disease
}

The production of several pro-inflammatory cytokines is increased in inflammatory bowel diseases (IBD). Experimental models of IBD have further defined the importance of specific cytokines for the induction of mucosal inflammation, by using specific neutralising antibodies, or by silencing cytokine genes in mice by using homologous recombination (knockout mice). ${ }^{12}$ Several therapeutic strategies are now being developed that either target pro-inflammatory cytokines or use recombinant anti-inflammatory cytokines in Crohn's disease and ulcerative colitis. Tumour necrosis factor- $\alpha$ (TNF- $\alpha$ ) is a cytokine which can transmit signals between immune and other cells, and is involved in (apoptotic) cell death, metabolism, inflammation, thrombosis, and fibrinolysis. In recent years, an important role for TNF- $\alpha$ as a pivotal pro-inflammatory mediator in Crohn's disease has emerged, and this has resulted in the development of several therapeutic strategies that target TNF- $\alpha$. This brief review discusses the current status of treatments targeting TNF- $\alpha$ and provides an outlook for future development.

\section{Regulation of TNF production}

Human TNF- $\alpha$ is a member of a large family of proteins and receptors that are involved in immune regulation. ${ }^{34}$ The secreted form of TNF- $\alpha$ is a $17 \mathrm{kD}$, non-glycosylated protein, circulating as a $51 \mathrm{kD}$ homotrimer that is mainly produced by monocytes, macrophages and T cells. Various stimuli, including endotoxin, superantigens, osmotic stress, and radiation, bring about release of TNF- $\alpha .{ }^{5}$ The gene encoding TNF- $\alpha$ is located on the short arm of chromosome 6 , between the HLA class I and II loci. ${ }^{6}$ The production of TNF- $\alpha$ is firmly regulated at the transcriptional, translational, and post-transcriptional levels, suggesting a need for protection against unregulated TNF- $\alpha$ release. The transcription of TNF- $\alpha$ by monocytes is down regulated by pretreatment with corticosteroids and various agents that increase the intracellular cyclic AMP concentration. ${ }^{7}$ Like other pro-inflammatory cytokines, TNF- $\alpha$ mRNA contains various UAUUAU-rich regions ("Kamen and Shaw regions") within the 3' untranslated region which greatly reduce mRNA half-life by acting as an RNAse attack site and by reducing the translation rate. ${ }^{8}$ TNF- $\alpha$ is translated as a $26 \mathrm{kD}$ precursor protein that contains an unusually long amino acid signal peptide. The enzyme that cleaves the propeptide to yield the secreted mature form has been identified as a specific metalloproteinase. Unclipped TNF- $\alpha$ remains membrane bound and is biologically active upon contact with neighbouring cells. ${ }^{9}$ Various metalloproteinase inhibitors reduce the release of $\mathrm{TNF}_{-} \alpha$, having no significant effect on the number of membrane expressed TNF- $\alpha$ molecules. ${ }^{10-12}$ Two specific transmembrane receptors, the type I $55 \mathrm{kD}$ and the type II $75 \mathrm{kD}$ TNF receptors, are expressed by most types of cells studied. ${ }^{13}$ The type II $75 \mathrm{kD}$ TNF receptor is also a receptor for lymphotoxin (also known as tumour necrosis factor- $\beta$ ). The events leading to signalling as well as the signal transduction pathways through the two TNF receptors have been reviewed recently. ${ }^{14}$ Various domains within the intracytoplasmic tail have been identified that specifically mediate apoptosis, activation of phospholipases and transduction of proliferation signals. Both TNF receptors can be proteolytically cleaved to yield soluble proteins that retain their capacity to bind released TNF- $\alpha^{15}{ }^{16}$ and, depending on the concentration of soluble receptor and the biological system studied, binding of TNF- $\alpha$ by soluble receptors may either neutralise or increase its biological activity.

\section{Biological activities of TNF}

TNF- $\alpha$ was independently recognised by its ability to mediate the necrosis of certain tumours in BCG sensitised mice, and its involvement in hypertriglyceridaemia and anorexia in experimental infectious disease. ${ }^{17-19}$ Subsequently, TNF- $\alpha$ has been characterised as a highly proinflammatory protein that is involved in the induction of fever, insulin resistance, bone resorption, anaemia, the activation of granulocytes and $\mathrm{T}$ cells, and in sepsis. ${ }^{20}$ Of relevance for IBD are the abilities of TNF- $\alpha$ to recruit circulating inflammatory cells to local tissue sites of inflammation, to induce oedema, to activate coagulation activation, and its pivotal role in granuloma formation.

Recruitment of neutrophils to local sites of inflammation is a consequence of a series of interactions of the circulating neutrophil and the endothelium, finally leading to transmigration. ${ }^{21}$ The first step is a weak interaction that is mediated by the selectin group of adhesion molecules, that leads to "rolling" of neutrophils over the inflamed endothelium. This intimate contact between neutrophils and endothelial cells causes increased expression of neutrophil $\beta 2$-integrin expression (in particular CD11b/ CD18) through activation by interleukin-8 (IL-8) and platelet-activating factor (PAF) which are expressed by endothelial cells. The subsequent interaction between CD11b/CD18 and its ligand on endothelial cells, intracellular adhesion molecule-1 (ICAM-1), leads to tight adhesion. Transmigration of neutrophils is in part mediated by PAF and IL-8. ${ }^{22}$ TNF- $\alpha$ promotes neutrophil-endothelial adhesion at various levels by up regulating the expression of endothelial cell selectins, by increasing the number of CD11b/CD18 molecules on neutrophil membranes, and by increasing the production of IL-8 by endothelial cells as well as epithelial cells (Fig 1). ${ }^{22-26}$ Following intravenous administration of TNF- $\alpha$ to healthy volunteers, circulating neutrophil counts decrease precipitously, and neutrophils become activated to release elastase and lactoferrin. ${ }^{27}$

Intravenous injection of TNF- $\alpha$ also induces both activation of coagulation and a rapid fibrinolytic response. ${ }^{2829}$ TNF- $\alpha$ dependent thrombin formation proceeds entirely through the extrinsic route of coagulation activation which depends on expression and activation of tissue factor. Contrary to what might be expected, fibrinolysis is not a 


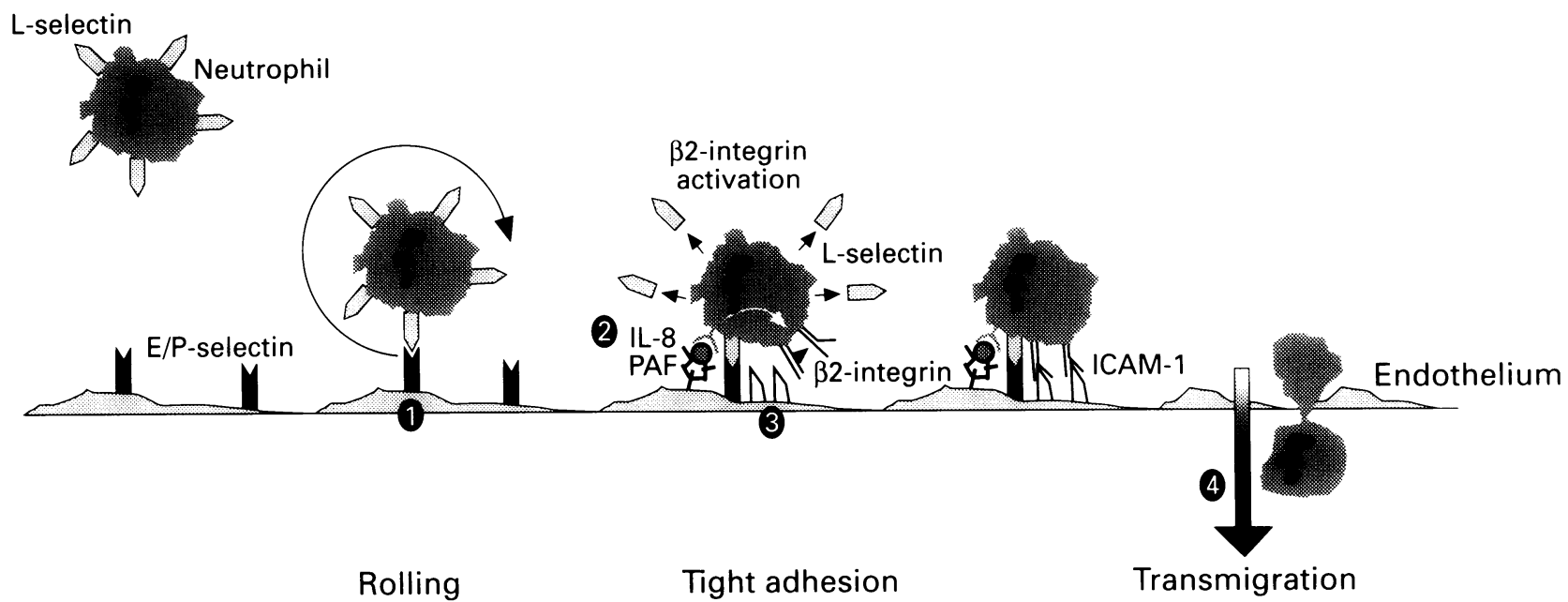

Figure 1: Recruitment of neutrophils into inflamed tissue results from rolling, tight adhesion and transendothelial migration. TNF- $\alpha$ promotes all three steps by increasing the expression of E/P-selectin by endothelial cells (1), by inducing the productiuon of PAF and IL-8 by endothelial cells (2), by increasing expression of ICAM-1 (3), and by inducing local production of various chemotactic substances, such as IL-8 and leukotriene $B_{7}(4)$.

consequence of thrombin formation, but seems to be regulated independently. In fact, in several models of experimental inflammation in humans and chimpanzees, fibrinolysis precedes activation of coagulation. Moreover, recent studies have suggested that whereas the effects of TNF on fibrinolysis result from direct activation, TNF- $\alpha$ induced thrombin formation is mediated by other cytokines, including interleukin-6 (IL-6). ${ }^{30}$ Neutralisation of $\mathrm{TNF}-\alpha$ in experimental endotoxaemia results in a virtually complete blockade of fibrinolysis, but thrombin formation is unaffected, presumably because endotoxin induced IL- 6 release is allowed to continue. ${ }^{31}$ Hence, in this model, TNF- $\alpha$ blockade results in a procoagulant state. None the less, in inflammatory conditions in which IL- 6 release is induced by TNF- $\alpha$ (and this may be the case in Crohn's disease) interference with $\mathrm{TNF}-\alpha$ production would be expected to block both activation of coagulation and fibrinolysis. Indeed, following infusion of the antiTNF- $\alpha$ antibody cA2, the abnormally increased intra- vascular thrombin formation in patients with active Crohn's disease rapidly returned to a normal rate. ${ }^{32}$

The presence of granulomas is one of the histopathological hallmarks of Crohn's disease. Granulomas are composed of T cells, monocytes and macrophages, and the recruitment of these cells is regulated by cytokines, such as interferon- $\gamma$, interleukin-1 $\beta, \mathrm{TNF}-\alpha$, and chemokines (Fig 2). Increased production of TNF- $\alpha$ has been shown in various models of granulomatous inflammation. ${ }^{33-35}$ The presence of CD4+ T cells and the production of TNF- $\alpha$ seem to be necessary for granuloma formation in several experimental models, ${ }^{36}{ }^{37}$ and neutralisation of TNF- $\alpha$ results in defective clearing of mycobacteria and other intracellular micro-organisms. ${ }^{38}{ }^{39}$ One of the mechanisms by which $\mathrm{TNF}-\alpha$ mediates granuloma formation is by regulating the production of the chemokine monocyte chemoattractant protein-1 (MCP-1) which is responsible for the chemotactic activity that recruits circulating monocytes into the site of granulomatous inflammation. ${ }^{40} 41$

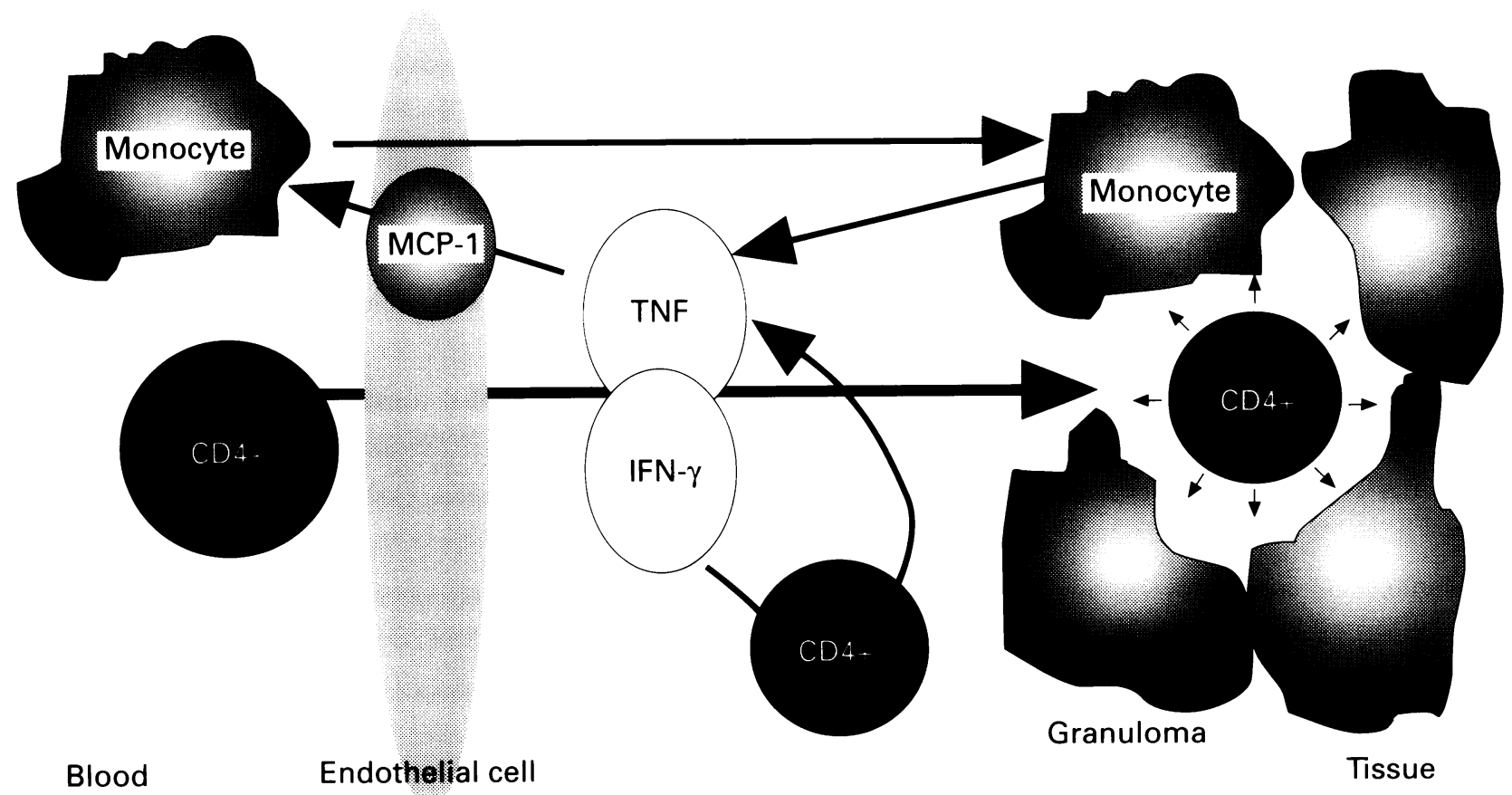

Figure 2: TNF- $\alpha$ is critical for granuloma formation. The source of TNF- $\alpha$ in these conditions has not been determined precisely, but both CD4+ T cells and monocytes are likely candidates. TNF- $\alpha$ dependent monocyte recruitment is medicated by production of MCP-1. 


\section{Evidence for increased mucosal TNF production in Crohn's disease}

The mucosal production of many cytokines is increased in active IBD, but it has been surprisingly difficult to detect increased TNF- $\alpha$ production in Crohn's disease. Several studies have now shown that the number of TNF- $\alpha$ producing lamina propria cells is increased in Crohn's disease. ${ }^{42} 43$ The distribution pattern of mucosal TNF- $\alpha$ producing cells in Crohn's disease and ulcerative colitis is different. In Crohn's disease, TNF- $\alpha$ positive cells can be detected throughout the mucosa, extending into the deep lamina propria. ${ }^{44}$ In ulcerative colitis, however, only subepithelial macrophages produce TNF- $\alpha$. It should be noted that the increased TNF- $\alpha$ production in Crohn's disease remains highly localised to the mucosa and the intestinal lumen. High concentrations of TNF- $\alpha$ can be detected in stools of children with active Crohn's disease, ${ }^{45}$ but serum concentrations are low, even in patients with very active disease. ${ }^{46}$ In contrast, the serum concentrations of both soluble TNF receptors are increased in active Crohn's disease. ${ }^{47}$

\section{Anti-TNF in animal models of IBD}

Animal models of IBD can be divided in those that depend on rather aspecific (chemical) damage to the intestinal mucosa, and those that are a consequence of abnormal immune activation. ${ }^{48}$ The recent development of the "immune mediated" models of IBD has permitted further characterisation of the role of TNF- $\alpha$. Transfer of CD4+ $T$ cells from normal mice to SCID mice (that lack $T$ cells) results in population of the gut and spleen by the donor cells, without causing disease. However, when only a sub-population of CD4+ cells (CD4+CD45RB ${ }^{\text {high }}$ ) is transferred, a severe and chronic pancolitis ensues. ${ }^{49}$ It is now known that after activation, $T$ cells differentiate, resulting in responses that can be divided according to the cytokines produced. Thl type responses are characterised by the production of predominantly IFN- $\gamma$, TNF- $\alpha$, lymphotoxin, and IL-2, and result in delayed-type hypersensitivity reactions. Th2 type responses result in the production of IL-4, IL-5, and IL-10. ${ }^{50} \mathrm{CD} 4+\mathrm{CD} 45 \mathrm{RB}^{\text {high }}$ $\mathrm{T}$ cells are thought to represent precursors of Th1 T cells and the mucosal inflammation that results from their transfer is indeed characterised by increased mucosal production of TNF- $\alpha$ and IFN- $\gamma$. Inhibition of Th1 responses in the $C D 4+C D 45 R^{\text {high }}$ transfer model using a single administration of anti-IFN- $\gamma$, or multiple doses of anti-TNF- $\alpha$ antibodies, prevented colitis or reduced its severity. ${ }^{51}$ Interestingly, the most efficient means of prevention of intestinal inflammation was to co-transfer CD4+CD45RB ${ }^{\text {low }}$ cells. ${ }^{52}$ Anti-TNF- $\alpha$ antibody treatment also reduced the severity of colitis induced by the hapten 2,4,6-trinitrobenzene sulphonic acid which is considered to be a Th1 dependent inflammatory reaction. ${ }^{53}$ These results, and data from other recently developed models, ${ }^{54} 55$ allow several important conclusions to be reached. First, abnormal immune regulation can result in intestinal inflammation in the absence of specific intestinal pathogens; second, a subset of T cells within the CD4+ compartment regulate other $\mathrm{CD} 4+$ cells to prevent uncontrolled activation within the mucosa; and third, such uncontrolled activation is characterised by increased production of TNF- $\alpha$ and IFN- $\gamma$. Another interesting model of IBD occurs in mice in which the gene encoding IL-10 has been silenced (IL-10 knockout mice). ${ }^{56}$ As expected, repeated administration of recombinant IL-10 prevents development of IBD in these mice, but interestingly administration of anti-IFN- $\gamma$ antibody also had beneficial effects. ${ }^{57}$ The effect of anti-TNF- $\alpha$ on the development of colitis has not been reported, but TNF- $\alpha$ was shown to be responsible for the extreme sensitivity of IL-10 knockout mice to croton oil. ${ }^{58}$ It should be noted that TNF- $\alpha$ neutralising interventions may also be beneficial in models that are not $\mathrm{T}$ cell dependent, such as colitis induced by dextran sulphate sodium. ${ }^{59}$ In conclusion, data from recent "immune mediated" models of experimental IBD have clearly defined a potent proinflammatory role for mucosal TNF- $\alpha$. Neutralisation of TNF- $\alpha$ by repeated administration of antibodies resulted in amelioration of mucosal inflammation in several models of $\mathrm{T}$ cell dependent inflammation.

\section{Treatment of Crohn's disease with anti-TNF}

Several studies have addressed the potential efficacy of anti-TNF- $\alpha$ treatment in Crohn's disease. The first patient to be treated with anti-TNF- $\alpha$ was a young girl with severe steroid refractory Crohn's colitis. The TNF- $\alpha$ antibody (cA2) used, a high affinity human/mouse chimeric antibody, was administered twice at a dose of $10 \mathrm{mg} / \mathrm{kg}$. Treatment was followed by a rapid decrease in the Crohn's disease activity index (CDAI), remarkable healing of mucosal ulcers and did not cause apparent side effects. ${ }^{60}$ Encouraged by this result, a second, open label study was performed in 10 patients with steroid refractory Crohn's disease who were treated with a single intravenous administration of anti-TNF- $\alpha$ antibody (cA2), at a dose of $10 \mathrm{mg} / \mathrm{kg}$ (eight patients) or $20 \mathrm{mg} / \mathrm{kg}$ (two patients). In all nine evaluable patients, a remarkable clinical response occurred, most achieving complete clinical remission (as defined by a decrease in the CDAI below 150), with evidence of healing of mucosal ulcers in all but one patient. Because of the non-blinded design of the study, these data should be interpreted cautiously, but other parameters measured strongly suggested that the anti-TNF- $\alpha$ antibody had a potent anti-inflammatory effect. For example, the serum $C$ reactive protein (CRP) concentration normalised in all patients, the circulating IL-6 concentration decreased, secreted phospholipase A2 activities dropped rapidly, and immunohistochemistry indicated a strong decrease in the mucosal expression of the chemokines MCP-1, MIP- $1 \alpha$ and RANTES. ${ }^{61}$ Furthermore, these results are very comparable with the very potent anti-inflammatory effects of anti-TNF- $\alpha$ in severe rheumatoid arthritis, a disease that shares several immunopathological features with Crohn's disease. ${ }^{62-64}$ Controlled studies to establish the clinical utility of antiTNF- $\alpha$ antibody therapy in patients with Crohn's disease have been initiated, and preliminary results from one study seem to confirm the clinical efficacy of this therapeutic approach. In this study, 108 patients with active Crohn's disease (CDAI between 220 and 400) were randomised to receive placebo, 5,10 , or $20 \mathrm{mg} / \mathrm{kg}$ anti-TNF antibody (cA2). A clinical response was defined as a reduction in the CDAI of more than 70 points, and clinical remission as a reduction in the CDAI below 150 in combination with a reduction in the CDAI by more than 70 points. ${ }^{65}$ AntiTNF treatment resulted in a significantly larger reduction in the CDAI measured four weeks after infusion $(-110$ points) than placebo $(-13$ points; $p<0.001)$, reduced $C R P$ concentrations, and caused a substantial increase in quality of life as measured by the IBDQ. Seventy per cent of patients showed a clinical response to cA2 treatment, whereas this occurred in only $24 \%$ of those treated with placebo. ${ }^{66}$ The clinical effects of cA2 therapy showed a correlation with down regulation of the production of the Th1 cytokine IFN- $\gamma$ by CD2 stimulated lamina propria mononuclear cells, whereas no effect was observed on cytokine production by stimulated peripheral blood 
mononuclear cells. ${ }^{67}$ This finding strongly indicates that the primary defect in immune regulation in Crohn's disease is confined to the mucosal compartment. The results of a small study using a different anti-TNF- $\alpha$ antibody (the mouse/human chimeric antibody CDP571) in patients with active Crohn's disease also suggested clinical benefit. ${ }^{68}$

These observations enable one to reach several conclusions. Clearly, TNF- $\alpha$ is an important mediator of intestinal inflammation in Crohn's disease. The rapid reduction in intravascular thrombin formation after treatment with anti-TNF- $\alpha$ strongly suggests that the procoagulant state in Crohn's disease is secondary to inflammation, rather than being a causal factor. AntiTNF- $\alpha$ seems to be a promising therapeutic strategy in patients who do not respond to standard treatment. Virtually all patients did relapse after induction of remission by a single dose of anti-TNF- $\alpha$ antibodies. Hence, maintenance of remission may require repeated infusions of the antibody, and clinical studies have been initiated to confirm this. No doubt, this therapy will be costly and long term administration of chimeric antibodies may be associated with side effects, in particular the induction of human anti-chimeric antibodies (HACA) which may interfere with the biological effects. Therefore, alternative anti-TNF- $\alpha$ interventions are being sought. $\mathrm{TNF}-\alpha$ neutralising proteins have been constructed that consist of two TNF- $\alpha$ receptors that are either linked to PEG or grafted on a protein backbone (that is, an IgG tail). ${ }^{69}$ Some of these proteins have a high capacity to inhibit $\mathrm{TNF}-\alpha$, and are currently under investigation in rheumatoid arthritis and sepsis. However, the $\mathrm{TNF}-\alpha$ inhibiting proteins need to be administered intravenously and although entirely composed of human protein sequences, may still be immunogenic. An alternative approach might be to interfere with $\mathrm{TNF}-\alpha$ transcription, translation or post-translational processing (Fig 3). Several drugs interfere with $\mathrm{TNF}-\alpha$ transcription by increasing intracellular cyclic AMP concentrations. ${ }^{7071}$ One of these drugs, oxpentifylline, has been studied in Crohn's disease, but failed to show clinical efficacy (see paper by Bauditz et al, page 470). There are several explanations for the discrepant effects of anti-TNF- $\alpha$ antibodies and oxpen- tifylline. First, it is not known which TNF- $\alpha$ producing cell (monocyte, macrophage, $\mathrm{T}$ lymphocyte) is contributing most to TNF production in Crohn's disease, and so far the effects of oxpentifylline on TNF- $\alpha$ production have been mainly studied in monocytes. Second, $\mathrm{TNF}-\alpha$ antibodies do bind to membrane expressed $T N F-\alpha$, and it is conceivable that this interaction either alters the function of the TNF- $\alpha$ producing cell, or results in killing through complement activation. ${ }^{72}$ Hence, other drugs that inhibit $\mathrm{TNF}-\alpha$ transcription are being developed, in particular drugs that inhibit nuclear translocation of $\mathrm{NF}_{\kappa} \mathrm{B}$, a DNA binding protein that is important for activation of transcription of the TNF gene. ${ }^{73}$ it Clipping of TNF- $\alpha$, which is necessary for release, can be prevented by inhibitors of the TNF- $\alpha$ converting enzyme. Indeed, several metalloproteinase inhibitors have been shown to reduce $\mathrm{TNF}-\alpha$ production in vitro and in vivo, and some are in clinical development. The recent cloning of the $\mathrm{TNF}-\alpha$ convertase will no doubt lead to the generation of more potent and specific inhibitors. However, it should be noted that $\mathrm{TNF}-\alpha$ convertase inhibitors reduce release of TNF- $\alpha$, but in general, do not decrease the expression of membrane bound TNF- $\alpha$. Although effectively blocking the release of $\mathrm{TNF}-\alpha$, in certain conditions metalloproteinase inhibitors do not prevent the $\mathrm{TNF}-\alpha$ dependent induction of secondary cytokines. ${ }^{75}$ This apparent paradoxical effect might be explained by accumulation of biologically active membrane bound $\mathrm{TNF}-\alpha$, or by the fact that metalloproteinase inhibitors also prevent proteolytic cleavage of both $\mathrm{TNF}-\alpha$ receptors. In fact, the application of TNF- $\alpha$ convertase inhibitors in clinical trials in IBD will answer the question whether released or membrane bound $\mathrm{TNF}-\alpha$ is more important. Furthermore, several metalloproteinase inhibitors are not specific for $\mathrm{TNF}-\alpha$ convertase, but also decrease clipping of the natural Fas ligand which is involved in apoptotic cell death and which plays an important role in immune regulation. ${ }^{76}$

\section{Conclusion}

Evidence to date suggests that TNF- $\alpha$ is an important proinflammatory mediator in Crohn's disease. These data have increased knowledge of the mechanisms of mucosal

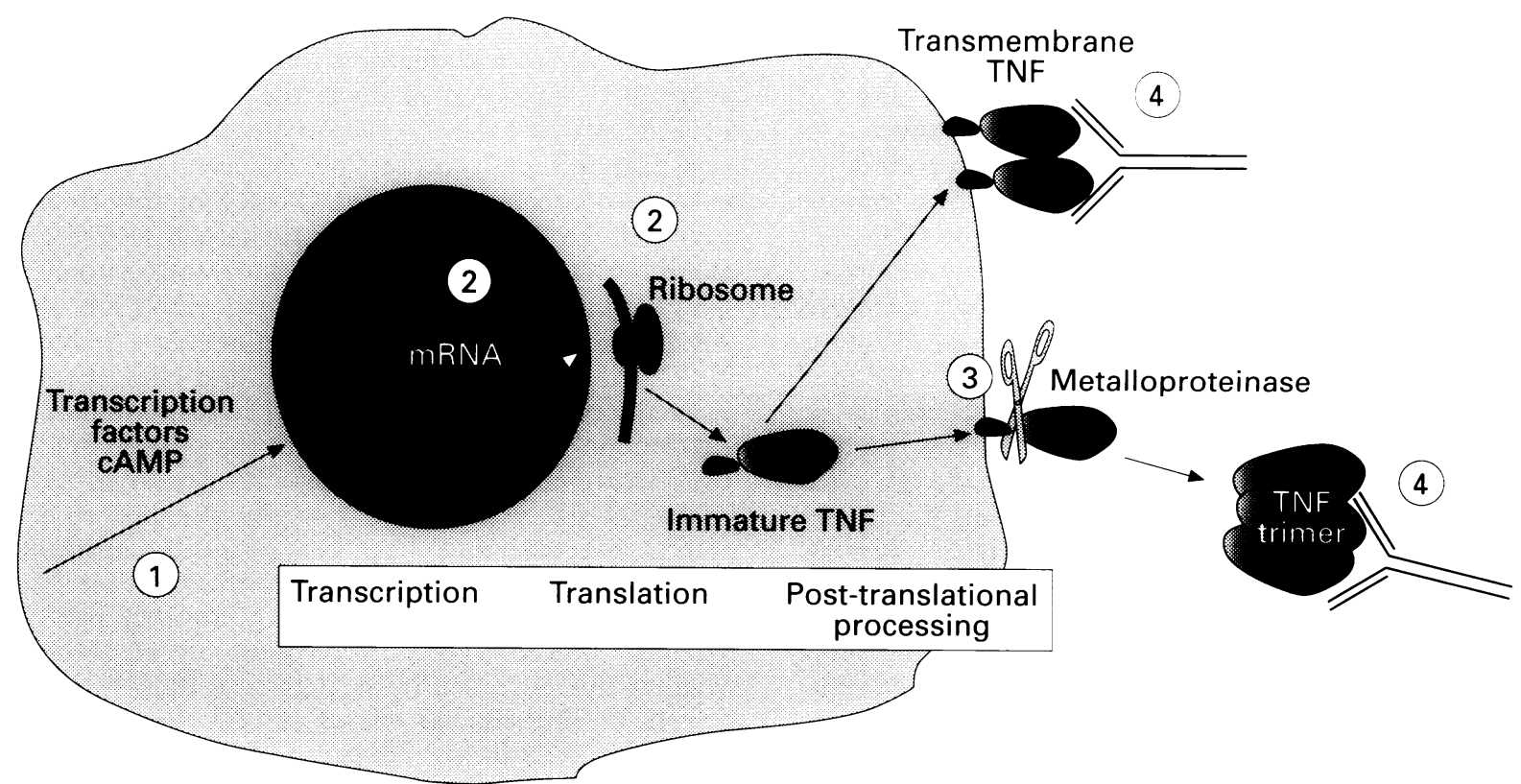

Figure 3: Pentoxifylline decreases TNF- $\alpha$ transcription by increasing the intracellular cyclic AMP concentrations (1). Corticosteroids decrease TNF- $\alpha$ $m R N A$ half life as well as the translation rate (2). Metalloproteinase inhibitors prevent release of TNF- $\alpha$ (3), but do not decrease the number of membrane bound molecules. Anti-TNF- $\alpha$ antibodies bind to released TNF- $\alpha$ trimers, but also to membrane bound TNF- $\alpha$ (4). 
inflammation and have resulted in the identification of a novel therapeutic target. Administration of anti-TNF- $\alpha$ antibodies to patients with active, therapy refractory Crohn's disease decreased disease activity and caused (transient) complete remission. The precise mechanism of action

of anti-TNF- $\alpha$ antibody therapy remains unknown and future studies will need to tackle the question whether this activity is mainly anti-inflammatory (by neutralisation of released TNF- $\alpha$ ) or mainly immune modulating (by altering the function of immune cells). The answers provided by such studies will be critical for the development of novel intervention strategies that target TNF- $\alpha$.

Laboratory for Experimental Internal Medicine,

$S$ J H VAN DEVENTER

Academic Medical Centre,

Meibergdreef 9 ,

1105 AZ Amsterdam,

The Netherlands

1 Sartor RB. Cytokines in intestinal inflammation: pathophysiological and clinical considerations. Gastroenterology 1994; 106: 533-9.

2 Elson CO, Sartor RB, Tennyson GS, Riddell RH. Experimental models of inflammatory bowel disease. Gastroenterology 1995; 109: 1344-67.

3 Farrah T, Smith CA. Emerging cytokine family. Nature 1992; 358: 26.

4 Beutler $\mathrm{B}$. An evolutionary approach to the TNF $\alpha$ receptor/ligand family. Ann NY Acad Sci 1994; 730: 118-33.

5 Manogue KR, van Deventer SJH, Cerami A. Tumour necrosis factor alpha or cachectin. In: Thomson AW, ed. Cytokine handbook. London: Academic Press, 1991: 241-56.

6 Carroll MC, Katzman P, Alicot EM, Koller BH, Gerathy DE, Orr HT, et al. Linkage map of the human histocompatibility complex including the tumor necrosis factor genes. Proc Natl Acad Sci USA 1987; 84: 8535-9.

7 Han J, Thompson P, Beutler B. Dexamethasone and pentoxifylline inhibit endotoxin-induced cachectin/tumor necrosis factor synthesis at separate points in the signaling pathway. $\mathcal{F}$ Exp Med 1990; 172: 391-4

8 Caput D, Beutler B, Hartog K, Thayer R, Brown-Shimer S, Cerami A Identification of a common nucleotide sequence in the 3'-untranslated region of mRNA molecules specifying inflammatory mediators. Proc Nat Acad Sci USA 1986; 83: 1670-4.

9 Perez C, Albert I, DeFay K, Zachariades N, Gooding L, Kriegler M. A nonsecretable cell surface mutant of tumor necrosis factor (TNF) kills by cell-to-cell contact. Cell 1990; 63: 251-8.

10 Gearing AJ, Beckett P, Christodoulou M, Churchill M, Clements J, Davidson $\mathrm{AH}$, et al. Processing of tumour necrosis factor-alpha by metalloproteinases. Nature 1994; 370: 555-7.

11 Mohler KM, Sleath PR, Fitzner JN, Cerretti DP, Alderson M, Kerwar SS et al. Protection against a lethal dose of endotoxin by an inhibitor of tumour necrosis factor processing. Nature 1994; 370: 218-20.

12 Crowe PD, Walter BN, Mohler KM, Otten-Evans C, Black RA, Ware CF. A metalloprotease inhibitor blocks shedding of the $80 \mathrm{kD}$ TNF $\alpha$ receptor and TNF $\alpha$ processing in T lymphocytes. $f$ Exp Med 1995; 181: 1205-10.

13 Tartaglia LA, Goeddel DV. Two TNF $\alpha$ receptors. Immunol Today 1992; 13: $151-3$

14 Bazzoni F, Beutler B. The tumor necrosis factor ligand and receptor families. $N$ Engl ₹ Med 1996; 334: 1717-25.

15 Lantz M, Gullberg U, Nilsson E, Olsson I. Characterization in vitro of a human tumor necrosis factor-binding protein. A soluble form of a tumor necrosis factor receptor. $\mathcal{F}$ Clin Invest 1990; 86: 1396-402.

16 Kohno T, Brewer MT, Baker SL. A second tumor necrosis factor receptor gene product can shed a naturally occurring tumor necrosis factor inhibitor. Proc Natl Acad Sci USA 1990; 87: 8331-5.

17 Old LJ. Tumour necrosis factor (TNF). Science 1985; 230: 630-3.

18 Beutler B, Mahoney J, Le Trang N, Pekala P, Cerami A. Purification of cachectin, a lipoprotein lipase-suppressing hormone secreted by endotoxin-induced RAW 264.7 cells. $\mathcal{F}$ Exp Med 1985; 161: 984-95.

19 Beutler B, Greenwald D, Hulmes JD, Chang M, Pan YC, Mathison J, et al. Identity of tumour necrosis factor and the macrophage-secreted factor cachectin. Nature 1985; 316: 552-4.

20 Tracey KJ, Cerami A. Tumor necrosis factor: a pleiotropic cytokine and therapeutic target. Ann Rev Med 1994; 45: 491-503.

21 Carlos TM, Harlan JM. Leukocyte-endothelial adhesion molecules. Blood 1994; 84: 2068-101.

22 Kuijpers TW, Hakkert BC, Hart MH, Roos D. Neutrophil migration across monolayers of cytokine-prestimulated endothelial cells: a role for plateletactivating factor and IL-8. F Cell Biol 1992; 117: 565-72.

23 Smart SJ, Casale TB. TNF-alpha-induced transendothelial neutrophil migration is IL-8 dependent. Am $\mathcal{f}$ Physiol 1994; 266: L 238-45.

24 Paleolog EM, Delasalle SA, Buurman WA, Feldmann M. Functional activities of tumor necrosis factor alpha on human vascular endothelial cells. Blood 1994; 84: 2578-90.

25 Schuerer-Maly CC, Eckmann L, Kagnoff MF, Falco MT, Maly FE. Colonic epithelial cell lines as a source of interleukin-8: stimulation by inflammatory cytokines and bacterial lipopolysaccharide. Immunology 1995; 81: 85-91.

26 Lammers KM, Jansen J, Bijlsma PB, Ceska M, Tytgat GN, Laboisse CL et al. Polarised interleukin-8 secretion by HT29/19A cells. Gut 1994; 35: 338-42.

27 Van der Poll T, van Deventer SJH, Hack CE, Wolbink CJ, Aarden LA Büller HR, et al. Effects on leukocytes after injection of tumor necrosis factor into healthy humans. Blood 1992; 79: 693-8.

28 Van der Poll T, Büller HR, ten Cate H, Wortel C, Bauer KA, van Deventer $\mathrm{SJH}$, et al. Activation of coagulation after administration of tumor necrosis factor to normal subjects. N Engl f Med 1990; 322: 1622-7.
29 Van der Poll T, Levi M, Büller HR, van Deventer SJH, de Boer JP, Hack CE, et al. Fibrinolytic response to tumor necrosis factor in healthy subjects. F Exp Med 1991; 174: 729-32.

30 Van der Poll T, Levi M, Hack CE, ten Cate H, van Deventer SJ, Eerenberg AJ, et al. Elimination of interleukin- 6 attenuates coagulation activation in experimental endotoxemia in chimpanzees. $\mathcal{F}$ Exp Med 1994; 179: 1253-9.

31 Van der Poll T, Levi M, van Deventer SJH, ten Cate H, Haagmans BL Biemond B, et al. Differential effects of anti-tumor necrosis factor monoclonal antibodies on systemic inflammatory responses in experimental endotoxemia in chimpanzees. Blood 1994; 83: 446-51.

32 Hommes DW, van Dullemen $H$, Levi $M$, van den Ende A, Woody J Tytgat GNJ, et al. The effect of anti-tumor necrosis factor chimeric monoclonal antibody (cA2) on markers of coagulation and fibrinolysis in patients with active Crohn's disease. In: Novel therapeutic approaches in inflammatory bowel disease [dissertation]. Amsterdam: Univ of Amsterdam, 1996

33 Tsuji M, Dimov VB, Yoshida T. In vivo expression of monokine and inducible nitric oxide synthase in experimentally induced pulmonary inflammation. Evidence for sequential production of interleukin-1, inducible nitric oxide synthase and tumor necrosis factor. Am $\mathcal{F}$ Pathol 1995; 147: 1001-15.

34 Chensue SW, Warmington KS, Ruth JH, Lincoln P, Kunkel SL. Cytokine function during mycobacterial and schistosomal antigen-induced pulmonary granuloma formation. Local and regional participation of IFN-gamma, IL-10 and TNF. F Immunol 1995; 154: 5969-76.

35 Myatt N, Coghill G, Morrison K, Jones D, Cree IA. Detection of tumour necrosis factor alpha in sarcoidosis and tuberculosis granulomas using in situ hybridisation. $\mathcal{F}$ Clin Pathol 1994; 47: 423-6.

36 Mielke ME, Rosen H, Brocke S, Peters C, Hahn H. Protective immunity and granuloma formation are mediated by two distinct tumor necrosis factor alpha and gamma-interferon-dependent T-cell-phagocyte interactions in murine listeriosis: dissociation on the basis of phagocyte adhesion mechanisms. Infect Immun 1992; 60: 1875-82.

37 Amiri P, Locksley RM, Parslow TG, Sadick M, Rector E, Ritter D, et al. Tumour necrosis factor alpha restores granulomas and induces parasite

38 Kindler V, Sappino AP, Grau GE, Piguet PF, Vassalli P. The inducing role of tumor necrosis factor in the development of bactericidal granulomas during BCG infection. Cell 1989; 56: 731-40.

39 Flynn JL, Goldstein MM, Chan J, Riebold KJ, Pfeffer K, Lowenstein CJ, et al. Tumor necrosis factor-alpha is required in the protective immune response against Mycobacterium tuberculosis in mice. Immunity 1995; 2 : 561-72.

40 Jones ML, Warren JS. Monocyte chemoattractant protein 1 in a rat model of pulmonary granulomatosis. Lab Invest 1992; 66: 498-503.

41 Flory CM, Jones ML, Miller BF, Warren JS. Regulatory roles of tumor necrosis factor alpha and interleukin 1 beta in monocyte chemoattractant
protein 1 mediated pulmonary granuloma formation in the rat. $A m \mathcal{F}$ Protein 1 mediated pulm 1995; 146: 450-62.

42 Breese EJ, Michie CA, Nicholls SW, Murch SH, Williams CB, Domizio P, et al. Tumor necrosis factor alpha-producing cells in the intestinal mucosa of children with inflammatory bowel disease. Gastroenterology 1994; 106: 1455-66.

43 Reinecker HC, Steffen M, Witthoeft T, Pflueger I, Schreiber S, MacDermott RP, et al. Enhanced secretion of tumour necrosis factoralpha, IL-6, and IL-1-beta by isolated lamina propria mononuclear cells from patients with ulcerative colitis and Crohn's disease. Clin Exp Immunol 1993; 94: 174-81.

44 Murch SH, Braegger CP, Walker-Smith JA, MacDonald TT. Location of tumour necrosis factor alpha by immunohistochemistry in chronic inflammatory bowel disease. Gut 1994; 35: 7105-9.

45 Braegger CP, Nichols S, Murch SH, Stephens S, MacDonald TT. Tumour necrosis factor alpha in stool as a marker of intestinal inflammation. Lancet 1992; 339: 89-91.

46 Nielsen OH, Brynskov J, Bendtzen K. Circulating and mucosal concentrations of tumour necrosis factor and inhibitor(s) in chronic inflammatory bowel disease. Dan Med Bull 1993; 40: 247-9.

47 Stronkhorst A, Jansen J, Tytgat GNJ, van Deventer SJH. Soluble IL2 and TNF receptor p 55 and p 75 in Crohn's disease [abstract]. Gastroenterology 1994; 104: 779A.

48 Elson CO, Sartor RB, Tennyson GS, Riddel RH. Experimental models of inflammatory bowel disease. Gastroenterology 1995; 109: 1344-67.

49 Leach MW, Bean AG, Mauze S, Coffman RL, Powrie F. Inflammatory bowel disease in C.B-17 scid mice reconstituted with the CD4+CD45RB ${ }^{\text {high }}$ subset of CD4+ T cells. Am $\mathcal{F}$ Pathol 1996; 148: $1503-15$.

50 Mosman TR, Sad S. The expanding universe of T-cell subsets - Th1, Th2 and more. Immunol Today 1996; 17: 138-46.

51 Powrie F, Leach MW, Mauze S, Menon S, Barcomb Caddle L, et al. Inhibition of $T h 1$ responses prevents inflammatory bowel disease in SCID mice reconstituted with $C D 45 \mathrm{RB}^{\text {high }} \mathrm{CD} 4+\mathrm{T}$ cells. Immunity 1994; 1 553-62.

52 Powrie F, Correa-Oliveira R, Mauze S, Coffman RL. Regulatory interactions between $C D 4+C D 45 R^{\text {high }}$ and $C D 4+C D 45 R B^{\text {low }} T$ cells
are important for the balance between protective and pathogenic cellmediated immunity. F Exp Med 1994; 179: 589-600.

53 Neurath M, Kollias R, Duchmann R, Fuss I, Strober W, Meyer zum Büschenfelde K-H. Effects of antibodies to TNF alpha on acute and chronic experimental colitis in mice. Gastroenterology 1997; in press.

54 Simpson SJ, Mizoguchi E, Allen D, Bhan AK, Terhorst C. Evidence that CD4+, but not CD8+ T cells, are responsible for murine interleukin-2 deficient colitis. Eur f Immunol 1995; 25: 2618-25.

55 Hollander GA, Simpson SJ, Mizoguchi E, Nichogiannopoulou A, She J, Guttierrez-Ramos JC, et al. Severe colitis in mice with abberant thymic Guttierrez-Ramos JC, et al. Severe
selection. Immunity 1995; 3: 27-38.

56 Kuhn R, Lohler J, Rennick D, Rajewski K, Muller W. Interleukin-10 deficient mice develop chronic enterocolitis. Cell 1993; 75: 203-5.

57 Berg DJ, Davidson N, Kühn R, Müller W, Menons S, Holland G, et al. Enterocolitis and colon cancer in interleukin-10 deficient mice are associated with abberant cytokine production and CD4+ Th1 responses. $\mathcal{F}$ Clin Invest 1996; 98: 10-20.

58 Rennick D, Berg D, Kühn R, Müller W. Interleukin-10 deficient mice. In De Vries J, De Waal Malefeyt R, eds. Interleukin-10. Landes Company, 1995: 141-8. 
59 Kojouharoff G, Hans W, Obermeier F, Schölmerich J, Andus T, Männel $\mathrm{D}$, et al. Reduction of inflammatory score by neutralization of tumor necrosis factor alpha (TNF) and not interleukin-1 (IL-1) in experimental dextrane sulphate-induced chronic colitis [abstract]. Gastroenterology 1996; 110: A940.

60 Derkx HHF, Taminiau J, Radema SA, Stronkhorst A, Wortel C, Tytgat GNJ, et al. Tumour necrosis factor antibody treatment in Crohn's disease [letter]. Lancet 1993; 342: 173-4.

61 Radema SA, van Dullemen H, Mevissen M, Jansen J, Tytgat GNJ, van Deventer SJH. Anti-TNF $\alpha$ therapy decreases production of chemokines in patients with Crohn's disease. In: Cytokine production immune activation, and neutrophil migration in inflammatory bowe disease [dissertation]. Amsterdam: Univ of Amsterdam, 1996

62 Elliott MJ, Maini RN, Feldmann M, Long-Fox A, Charles P, Bijl H, et al. Repeated therapy with monoclonal antibody to tumour necrosis factor alpha (cA2) in patients with rheumatoid arthritis. Lancet 1994; 344: 1125-7.

63 Elliott MJ, Maini RN, Feldmann M, Kalden JR, Antoni C, Smolen JS, et al. Randomised double-blind comparison of chimeric monoclonal antibody to tumour necrosis factor alpha (cA
rheumatoid arthritis. Lancet 1994; 344: 1105-10.

64 Feldmann M, Brennan FM, Elliott MJ, Williams RO, Maini RN. TNF alpha is an effective therapeutic target for rheumatoid arthritis. Ann NY Acad Sci 1995; 766: 272-8.

65 Targan SR, Rutgeerts P, Hanauer SB, van Deventer SJH, Mayer L Present DH, et al. A multicenter trial of anti-tumor necrosis factor (TNF) antibody (CA2) for treatment of patients with active Crohn's disease [abstract]. Gastroenterology 1996; 110: A1026.

66 Van Deventer SJH, Rutgeerts P, Targan SR, Hanauer SB, Mayer L, Present $\mathrm{D}$, et al. Anti-tumor necrosis factor antibody $\mathrm{CA} 2$ treatment induces clinical remissions in patients with Crohn's disease. Procedings of the 5th European Gastroenterology Week; 1996 Nov 2-6; London: BMJ Publishing Group, 1996.
67 Plevy SE, Carramanzana NM, Deem RL, Woody JN, Targan SR. Clinical improvement in Crohn's disease patients treated with anti-TNF alpha correlates with downregulated mucosal $\mathrm{T}$ helper 1 responses [abstract] Gastroenterology 1996, 110: A993

68 Stack W, Mann S, Roy A, Heath P, Sopwith M, Freeman J, et al. The effects of CDP571, an engineered human IgG-4 anti-TNF alpha antibody in Crohn's disease [abstract]. Gastroenterology 1996; 110: A1018

69 Van Zee KJ, Moldawer LL, Oldenburg HS, Thompson WA, Stackpole SA Montegut WJ, et al. Protection against lethal Escherichia coli bacteremia in baboons (Papio anubis) by pretreatment wit a $55 \mathrm{kDa}$ TNF receptor (CD120a)-IgG fusion protein, Ro 45-2081. F Immunol 1996; 156: 2221-30.

70 Giroir B, Beutler B. Effect of amrinone on tumor necrosis factor production in endotoxic shock. Circ Shock 1992; 36: 200-7.

71 Zabel P, Wolter DT, Schönharting MM, Schade UF Oxpentifylline in endotoxemia. Lancet 1989; ii: 1474-7.

72 Scallon BJ, Moore MA, Trinh H, Knight DM, Ghrayeb J. Chimeric antiTNF-alpha monoclonal antibody cA2 binds recombinant transmembrane TNF-alpha and activates immune effector functions. Cytokine 1995; 7 251-9.

73 Albrecht H, Schook LB, Jongeneel CV. Nuclear migration of NF-kappa B correlates with TNF-alpha mRNA accumulation. 7 Inflamm 1995; 45: 64-71.

74 Jongeneel CV. Regulation of the TNF alpha gene. Prog Clin Biol Res 1994; 388: 367-81.

75 Williams LM, Gibbons DL, Gearing A, Maini RN, Feldmann M Brennan FM. Paradoxical effects of a synthetic metalloproteinase inhibitor that blocks both p 55 and p 75 TNF receptor shedding and TNF alpha processing in RA synovial membrane cell cultures. $\mathcal{f}$ Clin Invest 1996; 97: 2833-41.

76 Kayagaki N, Kawasaki A, Ebata T, Ohmoto H, Ikeda S, Inoue S, et al. Metalloproteinase-mediated release of human Fas ligand. $\mathcal{F}$ Exp Med 1995; 182: 1777-83. 